Received 27.02.2017 Reviewed 31.03.2017 Accepted 10.04.2017

A - study design

B - data collection

C - statistical analysis

D - data interpretation

$\mathbf{E}$ - manuscript preparation

F - literature search

\section{Land cover changes in catchment areas of lakes situated in headwaters of the Tyśmienica River}

\author{
Antoni GRZYWNA ${ }^{1) A B D E F} \bowtie$, Joanna SENDER ${ }^{2) A C E F}$
}

\author{
1) University of Life Sciences in Lublin, Department of Environmental Engineering and Geodesy, Leszczyńskiego 7 Street, \\ 20-069 Lublin, Poland; e-mail: antoni.grzywna@up.lublin.pl \\ 2) University of Life Sciences in Lublin, Department of Landscape Ecology and Nature Conservation, Dobrzańskiego 37 \\ Street, 20-212 Lublin, Poland; e-mail: joanna.sender@up.lublin.pl
}

For citation: Grzywna A., Sender J. 2017. Land cover changes in catchment areas of lakes situated in headwaters of the Tyśmienica River. Journal of Water and Land Development. No. 33 p. 65-71. DOI: 10.1515/jwld-2017-0020

\begin{abstract}
The paper presents the history of land cover changes in the catchment area of lakes situated in the headwaters of the Tyśmienica River. The basis of the study were topographic maps in scale 1:50 000, from 1936 and 2014. We analyzed the quantitative aspect of these changes. The study was conducted in three natural lakes (Rogóźno, Krasne, Łukcze), and in one lake transformed into a storage reservoir (Krzczeń). The technical issues of georeferencing maps in the Geographic Information System (GIS) software are addressed first. In the landscape of Łęczna and Włodawa Lake District, to the end of the 19th century wetlands and bushes dominated. The first type of human pressure on this area was agriculture. Another type of pressure was recreation. In the catchment areas of studied lakes increased mainly the area of buildings and forests. Significantly increased also the length of roads and watercourses. Almost completely disappeared bushes and wastelands. In most of the analyzed basins, the area of wetlands and arable lands decreased. The probable cause of the changes in catchment use was decline in the water table, and thus overgrowing of meadows and wetlands.
\end{abstract}

Key words: lake basin, land use, topographic maps, Tyśmienica River

\section{INTRODUCTION}

Issues related to water management have been undertaken already in ancient Mesopotamia. More than 4000 years ago in Egypt the navigable canal was dug. It went round the famous rapids of the Nile River. The inception of the first ditches dates back to 3200 years BC [KAJAK 2001]. The Code of Hammurabi, who ruled Babylon nearly 4000 years ago, included management rules of irrigation channels. In the Chinese province - Seczuan, about 250 years BC the channel network, about $1000 \mathrm{~km}$ length was established. It stopped spring flood waters of the Min River and distributed them to the area of 200000 ha [CHMIELEWSKI, RADWAN 1993]. One of the seven wonders of the world, are the gardens of Babylon (7th century BC), which are irrigated by system of water channels.

The questions of hydraulic engineering and water management were carried out in ancient times, however, the genesis of contemporary sense and technical implementation of water management is relatively young. The concept of water management appeared for the first time in the early 20th century. The water shortages, in the countries of the temperate climate zone with the rapid progress of industrialization and population growth, started to be felt. The existing sources of water, have proved inadequate or poor quality, and the legal regulations have limited coverage [KOWALIK et al. 2014; SMOROŃ et al. 2009].

In order to eliminate the effects of drought and floods, as well as the economic activity of the region, in the Lublin Polesie area was built one of the longest 
water canals in Poland. The Canal Wieprz-Krzna (KWK) drainage system with a length of $142 \mathrm{~km}$ was built between 1954 and 1961. It begins near the village Borowica, where load water from the Wieprz River, while it flows into the Krzna River, in the vicinity of Miedzyrzec Podlaski. The initial width of the channel is $7 \mathrm{~m}$ and $14 \mathrm{~m}$ at the mouth. The Canal affects the area of 527.6 thousand hectares, and includes 60 lakes [PICHLA, JAKIMIUK 2014; RADWAN, KORNIJów 1994].

The aim of the study was to assess changes in land use in the catchment area of lakes, located in the headwater section of the Tyśmienica River, as well as hydrological relations, before and after construction of the drainage system in this area.

\section{STUDY AREA}

The Lęczna-Włodawa Lake District is classified as macroregion of Lublin Polesie [KONDRACKI 2002]. The Lake District with an area of $1160 \mathrm{~km}^{2}$ is typical tourist region [MAŚLANKO, SENDER 2012]. The difference in altitude is very small and amount to $50 \mathrm{~m}$. The region is characterized by the presence of dozens of shallow lakes, created as a result of the last glaciation. Still in the 50s, there were 68 natural lakes in this area [WILGAT 1954]. Currently, as a result of mainly the anthropogenic changes, remained 61 lakes [CHMIELEWSKI (ed.) 2009].

In the middle of 19th century, the Tyśmienica River had its beginning in the lake Krzczeń. The major reclamation works were performed at the turn of the century. As a result of hydrotechnical works, the length of the river increased from $68 \mathrm{~km}$ to $74.5 \mathrm{~km}$, and its spring was moved to the Lake Rogóźno with spring-area ditches reaching the Niedźwieckie marshes [CZARNECKA (ed.) 2005; GRZYWNA, MAZUR 2014].

In the $70 \mathrm{~s}$ of the 20th century, most of the lakes was incorporated into the drainage system KWK. Some of the reservoirs are used to fisheries management [HARASIUMIUK et al. (ed.) 1998]. The Łęczna and Włodawa Lake District is covered by several forms of protection, such as: Unesco Biosphere Reserve, the Poleski National Park, Natura 2000 "Jeziora Uściwierskie" [KRUKOWSKA 2007].

All studied reservoirs are located in the basin of the upper Tyśmienica. For research we selected three natural lakes (Łukcze, Rogóźno, Krasne) and one converted into a retention reservoir (Krzczeń).

Lake Lukcze $\left(51^{\circ} 23^{\prime} 49^{\prime \prime} \mathrm{N}\right.$; $\left.22^{\circ} 57^{\prime} 58^{\prime \prime} \mathrm{E}\right)$ is the smallest and the shallowest among the studied lakes, its area is 56.5 ha and the maximum depth $9 \mathrm{~m}$. The length of the shoreline is $3.9 \mathrm{~km}$ and the capacity of the reservoir is $2091 \mathrm{~m}^{3}$. Lake Rogóźno $\left(51^{\circ} 22^{\prime} 36^{\prime \prime} \mathrm{N}\right.$; $\left.22^{\circ} 58^{\prime} 21^{\prime \prime} \mathrm{E}\right)$ covers an area of 57.1 ha and is relatively deep $-25.4 \mathrm{~m}$. The length of the shoreline is $3.3 \mathrm{~km}$ and its capacity is $4209 \mathrm{~m}^{3}$. Lake Krasne $\left(51^{\circ} 25^{\prime} 35^{\prime \prime} \mathrm{N}\right.$; $\left.22^{\circ} 57^{\prime} 31^{\prime \prime} \mathrm{E}\right)$ is the deepest $(33 \mathrm{~m})$ and the largest (75.9 ha) among the studied lakes. The length of the shoreline is about $3.6 \mathrm{~km}$, while the ca- pacity approach $8180 \mathrm{~m}^{3}$ [HARASIMIUK et al. (ed.) 1998]. Originally natural lake Krzczeń was transformed into a storage reservoir in the $60 \mathrm{~s}$ of the 20th century. Krzczeń reservoir $\left(51^{\circ} 23^{\prime} 59.64\right.$ 'N; $\left.22^{\circ} 56^{\prime} 5.03^{\prime \prime} \mathrm{E}\right)$, before the KWK construction was a lake with an area only 20 ha and a maximum depth $5.2 \mathrm{~m}$. Currently it occupies an area of $160 \mathrm{ha}$. The length of the shoreline of the reservoir is about $6.7 \mathrm{~km}$ and capacity is $3300 \mathrm{~m}^{3}$.

\section{STUDY METHODS}

Cartographic analysis were carried out using the following maps: a topographic map and a map of land use Corine Land Cover 2012, as well as Tactical map of Military Geographical Institute (WIG) 1:100 000 (sheet P43 S36 Łęczna, published in 1938), system 1965 in Polish 1: 50000 map (sheet 136.2 Puchaczów, with situation dated to a 1967 in analyzed the area and the visualization of vector VMap Level2 2014 accessed via Polish Geoportal 1: 50,000.

The maps were georectified using ArcMap (version 10.2) of ArcGIS software package. Due to the problematic projection and reference systems of these maps, they were registered using mainly topographic features, not the topographic graticule. The geo-referencing process produced a reliable material. Areal and linear forms of land use were determined on maps. Distinguished among the areal forms were: building areas, arable lands, grasslands, wetlands, woodlands, wastelands, lakes and ponds. In case linear feature, roads and watercourses were digitized.

In order to isolate a group of lakes similar to each other (with regard to height above sea level, and management of the basin), we applied a non-hierarchical cluster analysis method. We determined the relationship between different forms of land use in lake basin and location above sea level, using Spearman's rank correlation coefficient.

\section{RESULTS}

The largest catchment area, among studied lakes, surrounded Lake Krasne (865.42 ha), while the smallest one was around the Lake Lukcze (468.65 ha). The catchment area of Krzczeń reservoir covered the surface 296.80 ha (Tab. 1).

Forests and farmlands dominated in the use of the Lake Rogóźno basin both 1936 and 2014 occupying about $35 \%$. Unlike to other studied catchments, in the past did not occur here concrete areas of wastelands (Tab. 1). The biggest differences in the catchment concerned the reduction of the arable lands and their allocation under afforestation (Tab. 2, Fig. 1). As a result, a fivefold increase in the length of watercourses in 2014, area of wetlands decreased about $50 \%$. The layout and length of roads did not undergo a large changes (Tab. 3 and 4).

In 1936, the catchment area of Lake Łukcze was dominated by arable lands. Under the touristic pres- 
Table 1. Management of catchment area of studied lakes (ha) in 1936 and 2014

\begin{tabular}{|l|c|c|c|c|c|c|c|c|}
\hline \multirow{2}{*}{ Land cover } & \multicolumn{2}{|c|}{ Lake Rogóźno } & \multicolumn{2}{c|}{ Lake Lukcze } & \multicolumn{2}{c|}{ Lake Krasne } & \multicolumn{2}{c|}{ Lake Krzczeń } \\
\cline { 2 - 10 } & 1936 & 2014 & 1936 & 2014 & 1936 & 2014 & 1936 & 2014 \\
\hline Wetlands & 57.06 & 28.61 & 17.09 & 15.15 & 44.77 & 37.33 & 87.22 & 53.86 \\
\hline Buldings & 80.64 & 88.72 & 41.49 & 122.00 & 37.66 & 54.68 & 3.53 & 22.93 \\
\hline Forests & 193.56 & 266.92 & 0 & 81.50 & 0 & 65.31 & 0 & 0 \\
\hline Arable lands & 334.12 & 273.35 & 255.70 & 137.13 & 483.27 & 423.00 & 48.56 & 0 \\
\hline Water lands & 55.36 & 53.35 & 60.37 & 58.97 & 153.74 & 160.19 & 19.00 & 161.70 \\
\hline Grasslands & 51.36 & 61.15 & 0 & 53.90 & 51.59 & 124.91 & 70.38 & 48.30 \\
\hline Wastelands & 0 & 0 & 94.00 & 0 & 94.39 & 0 & 68.11 & 10.01 \\
\hline Total & 772.10 & 772.10 & 468.65 & 468.65 & 865.42 & 865.42 & 296.80 & 296.80 \\
\hline
\end{tabular}

Source: own study.

Table 2. Changes in management of catchment area of studied lakes

\begin{tabular}{|c|c|c|c|c|c|c|c|c|}
\hline \multirow{2}{*}{ Land cover } & \multicolumn{2}{|c|}{ Lake Rogóźno } & \multicolumn{2}{|c|}{ Lake Łukcze } & \multicolumn{2}{|c|}{ Lake Krasne } & \multicolumn{2}{|c|}{ Lake Krzczeń } \\
\hline & ha & $\%$ & ha & $\%$ & ha & $\%$ & ha & $\%$ \\
\hline Wetlands & -28.45 & -49.86 & -1.86 & -10.68 & -7.44 & -16.61 & -33.36 & -38.25 \\
\hline Buldings & 8.08 & 10.02 & 80.51 & 194.05 & 17.02 & 45.18 & 19.40 & 549.58 \\
\hline Forests & 73.36 & 37.90 & 81.50 & $\mathrm{~N}$ & 65.31 & $\mathrm{~N}$ & - & - \\
\hline Arable lands & -60.77 & -18.19 & -118.57 & -46.37 & -60.27 & -12.47 & -48.56 & $\mathrm{Z}$ \\
\hline Water lands & -2.01 & -3.63 & -1.40 & -2.32 & 6.45 & 4.20 & 142.70 & 751.05 \\
\hline Grasslands & 9.79 & 19.06 & 53.90 & $\mathrm{~N}$ & 73.32 & 142.13 & -22.08 & -31.37 \\
\hline Wastelands & - & - & $-94,00$ & $Z$ & -94.39 & $\mathrm{Z}$ & -58.10 & -85.30 \\
\hline
\end{tabular}

Explanations: $\mathrm{N}=$ new form, $\mathrm{Z}=$ disappearance of the old form of use. Source: own study.

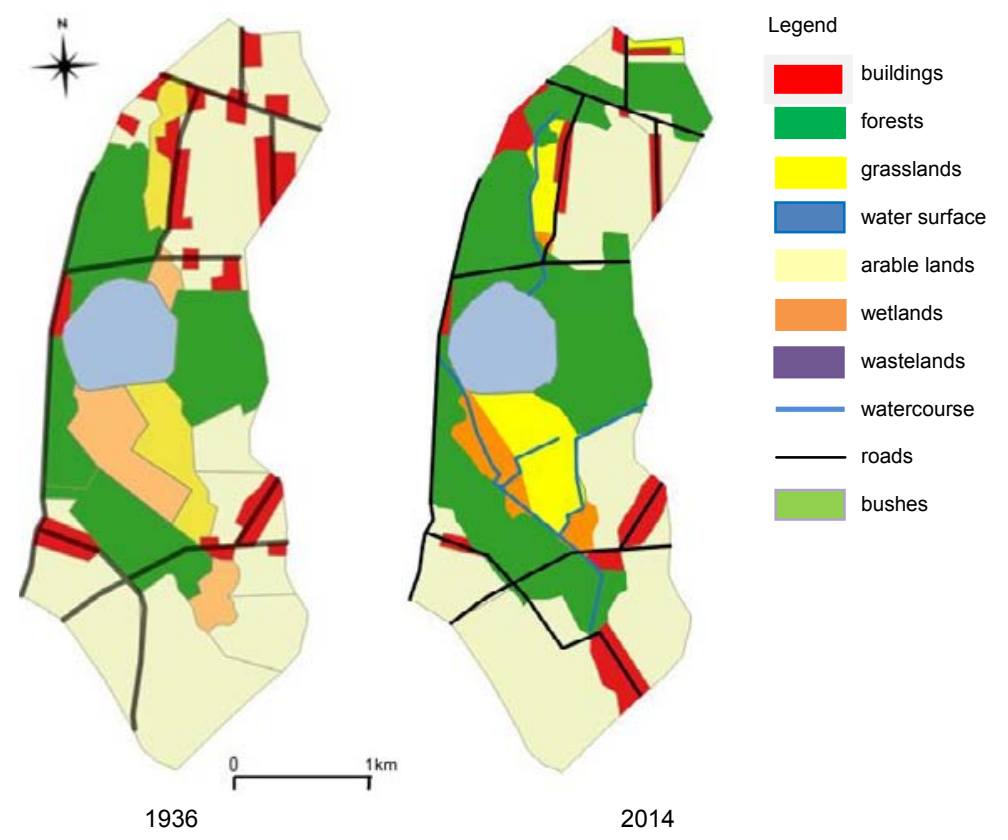

sure (from 70 s of the 20th century), the surface of arable lands decreased nearly $50 \%$ and the surface of buildings increased triply (Tab. 1 and 2). Numerous recreational buildings appeared mainly in the eastern and southern side of the lake. Completely disappeared bushes (Fig. 2), and in their place appeared forest lands and grasslands, that were not observed here before. In the catchment area of the lake Łukcze $3.5 \mathrm{~km}$ of ditches were built. It caused the disappearance of wetlands in the northern part of the catchment area, and the appearance of them in the center part. As compared to 1936, the length of roads has also increased by $1.3 \mathrm{~km}$, mainly in the area of buildings (Tab. 3 and 4).

Fig. 1. Management in catchment area of Lake Rogóźno in 1936 and 2014; source: own study

Table 3. Linear forms in the catchment area of studied lakes $(\mathrm{km})$ in 1936 and 2014

\begin{tabular}{|l|c|c|c|c|c|c|c|c|}
\hline \multirow{2}{*}{ Lake feature } & \multicolumn{2}{|c|}{ Rogóźno } & \multicolumn{2}{c|}{ Lukcze } & \multicolumn{2}{c|}{ Krasne } & \multicolumn{2}{c|}{ Krzczeń } \\
\cline { 2 - 10 } & 1936 & 2014 & 1936 & 2014 & 1936 & 2014 & 1936 & 2014 \\
\hline Roads & 12.70 & 12.90 & 8.70 & 10.00 & 7.70 & 10.70 & 4.80 & 5.10 \\
\hline Watercourse & 1.40 & 6.10 & 0 & 3.50 & 4.60 & 7.63 & 2.13 & 5.66 \\
\hline
\end{tabular}

Source: own study.

Table 4. Changes of linear forms in the catchment area of studied lakes $(\mathrm{km})$ in 1936 and 2014

\begin{tabular}{|l|c|c|c|c|c|c|c|c|}
\hline \multirow{2}{*}{ Lake feature } & \multicolumn{2}{|c|}{ Rogóźno } & \multicolumn{2}{c|}{ Łukcze } & \multicolumn{2}{c|}{ Krasne } & \multicolumn{2}{c|}{ Krzczeń } \\
\cline { 2 - 11 } & $\mathrm{km}$ & $\%$ & $\mathrm{~km}$ & $\%$ & $\mathrm{~km}$ & $\%$ & $\mathrm{~km}$ & $\%$ \\
\hline Roads & 0.20 & 1.57 & 1.30 & 14.94 & 3.00 & 38.96 & 0.30 & 6.25 \\
\hline Watercourse & 4.70 & 335.71 & 3.50 & $\mathrm{~N}$ & 3.03 & 65.87 & 3.53 & 165.73 \\
\hline
\end{tabular}

Explanations: $\mathrm{N}=$ new form. Source: own study. 
In the catchment area of the lake Krasne, both in the 30's and currently, dominated farmlands. However, during the 78 years the area of arable lands decreased about 60 ha, while appeared coppices and bushes (Tab. 1). The wastelands have been replaced by grasslands, and their surface increased 2.5 times. Significantly increased also the area of the buildings, about $45 \%$ (Tab. 2, Fig. 3). In 2014, even $20 \%$ of catchment area of the lake was covered with water bodies (lake and ponds). The length of ditches and roads increased by $3 \mathrm{~km}$ compared to 1936 (Tab. 3 and 4).

In 1936, the management of catchment area of Krzczeń reservoir was dominated by swamps and wastelands, which together covered $55 \%$ of the area. As a result of land flooding, the surface of water reservoir increased to 142 ha (8 times). Currently, the reservoir covers $56 \%$ of the catchment area. Completely disappeared fields, and in their place appeared grasslands (Fig. 4). During the 78 years the surface of wetlands and wastelands decreased significantly. In contrast, on the western shore of the lake the surface of buildings increased (Tab. 1 and 2). Despite the watercourse flowing through the reservoir was eliminated, the length of the ditches increased by more than $3.5 \mathrm{~km}$ (Tab. 3 and 4).

The nonhierarchical method (clustering of 3 medium) was used. It allows on indication of variables, which play an important role in the division of aggregation. The most important turned out to be: the height of land above $165 \mathrm{~m}$ a.s.l., the area of wetlands, forests and arable lands $(p<0.05)$. Very strong and positive correlation occurred between the surface of arable lands and the area at an altitude of 170-173 m above the sea level $(r=0.8697)$. Because the ShapiroWilk test rejected the normality of some studied features, the non-parametric Wilcoxon test was used. We investigated whether the average area of individual forms of land use has changed since 1936. Significant changes have taken place in the case of forests, grasslands and arable lands. In other cases, there were no statistically significant differences (Tab. 5).
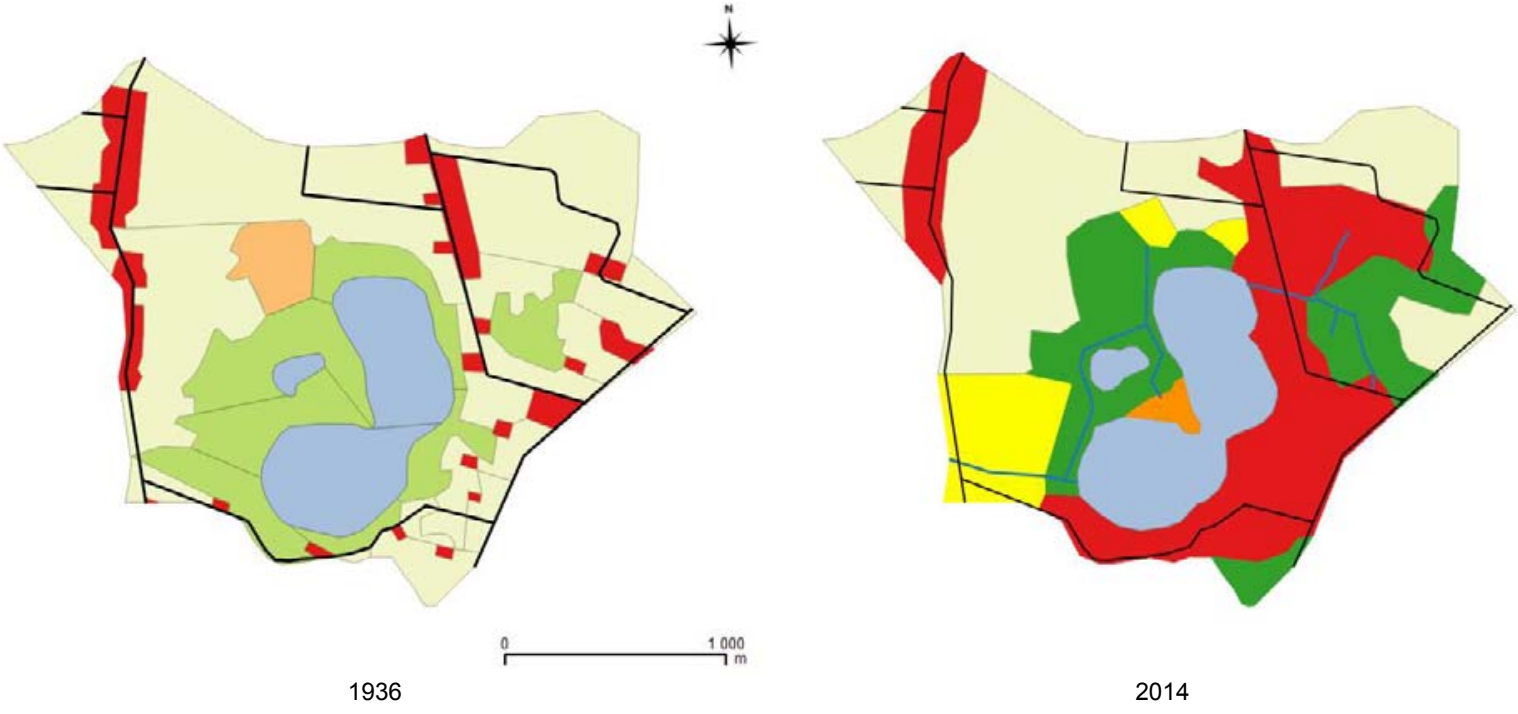

Fig. 2. Management in catchment area of Lake Łukcze in 1936 and 2014 (legend at fig. 1); source: own study

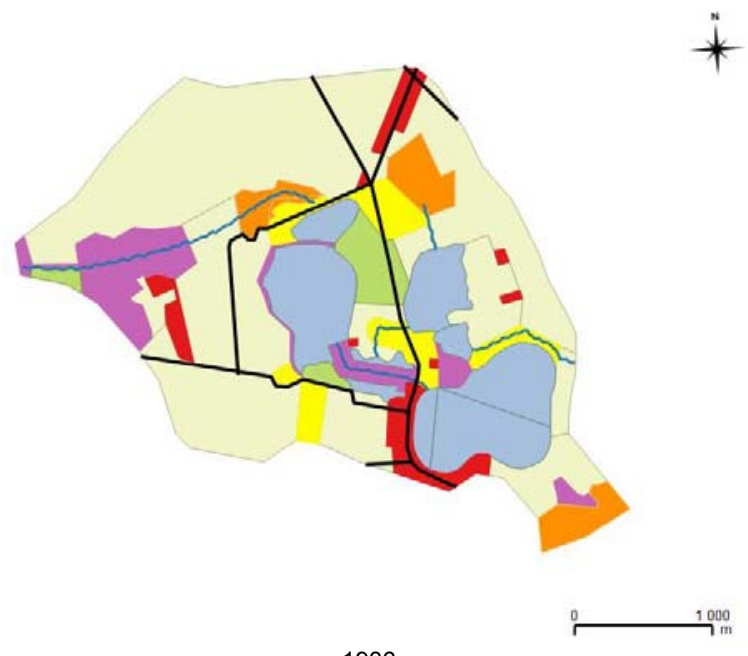

1936

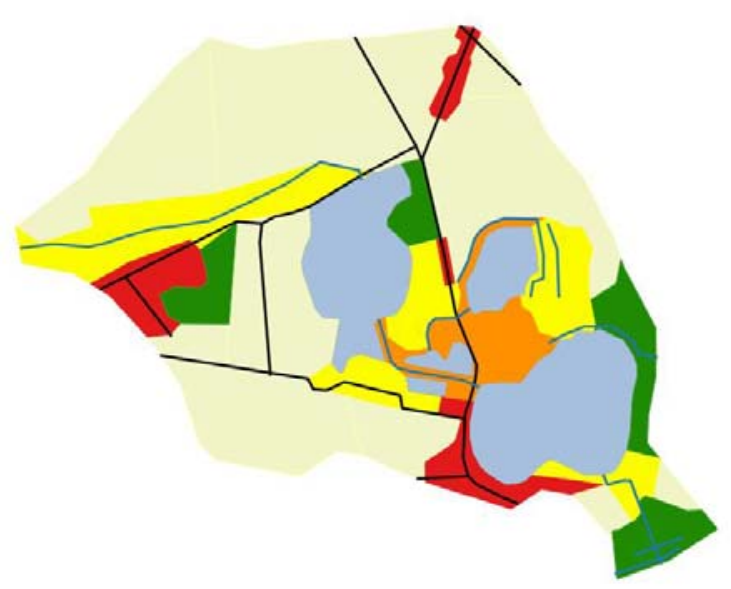

2014

Fig. 3. Management in catchment area of Lake Krasne in 1936 and 2014; legend at Fig. 1; source: own study 

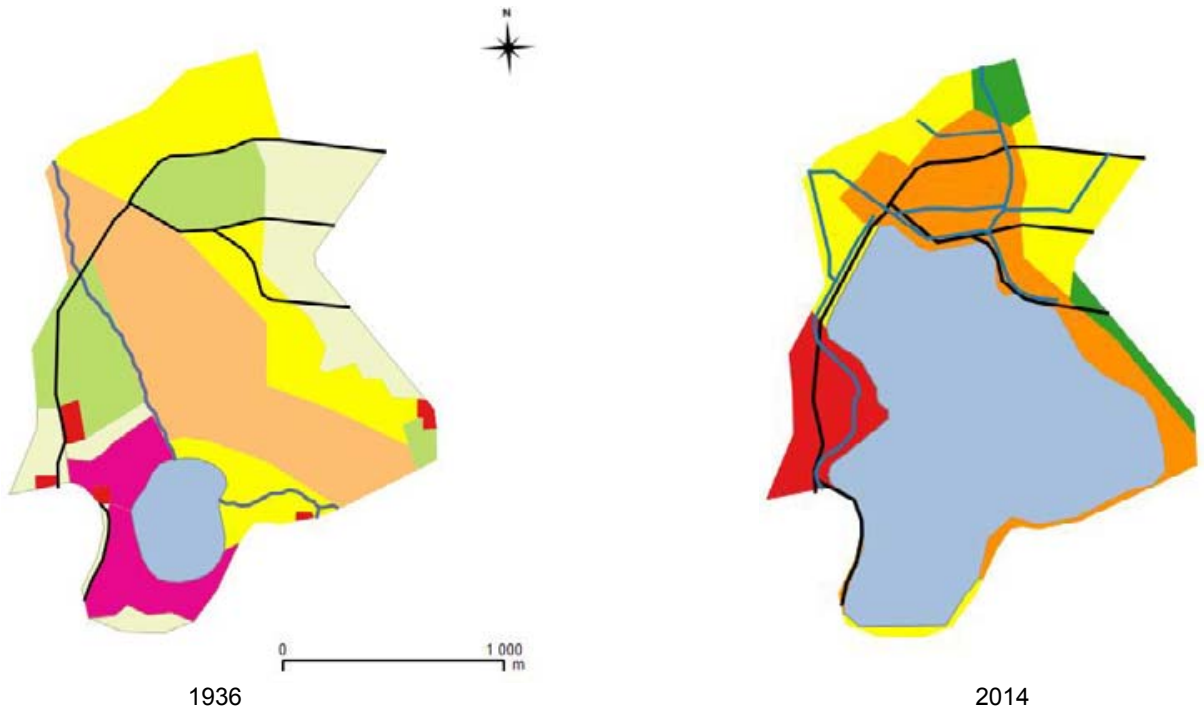

Fig. 4. Management in catchment area of Krzczeń reservoir in 1936 and 2014; legend at Fig. 1; source: own study

Table 5. Variance analysis $(d f=3)$

\begin{tabular}{|l|r|l|}
\hline \multicolumn{1}{|c|}{ Variable } & $F$ & \multicolumn{1}{c|}{$p$} \\
\hline Buldings & 0.32220 & 0.746867 \\
\hline Wetlands & 13.54505 & 0.031481 \\
\hline Grassland & 22.79918 & $0.015337^{*}$ \\
\hline Forest & 16.49532 & $0.024066^{*}$ \\
\hline Water & 1.65939 & 0.327140 \\
\hline Arable land & 29.06613 & $0.010871^{*}$ \\
\hline Wasteland & 10.21368 & 0.045824 \\
\hline
\end{tabular}

Explanation: * statistical significant. Source: own study.

\section{DISCUSSION}

By the end of the 19th century wetlands and bushes dominated in the landscape of Łęczna-Włodawa Lake District. A significant growth of population after the First and the Second World War led to an increase in demand for food. At that time there was strong pressure from agriculture. It indicated the necessity an increase in the agricultural area. Adaptation of the wetlands has been associated with construction of drain network and irrigation canals. Across the area of Łęczna-Włodawa Lake District, one of the longest in Poland, irrigation canal was constructed. An appropriate amount of water would provide a network of reservoirs: 6 dammed lakes and 5 newly created storage reservoirs [SOLIS 2012].

The construction of Wieprz-Krzna drainage system contributed to the negative changes in water conditions, causing a decrease in water level in lakes and in soil [RADWAN, KORNIJÓw 1994], as well as increased the rate of outflow, reduction of natural retention, as well as channeling of external, highly eutrophic waters [CHMIELEWSKI, RADWAN 1993]. Since 2005, as a result of decapitalization of equipment, irrigation of grassland, gradually discontinued. In the 21 st century, the demand for Polish food has decreased, it contributed to extensive agricultural use of the studied area. This situation leads to the running wild the landscape of this area [CHMIELEWSKI (ed.) 2009].
Another type of pressure on the landscape, in this area, was the turism development. In the 70 s of the 20th century, by the lakes, started to appear many resorts. Around the public resorts, began to build private recreational cottages. Currently, the shorelines of many lakes are available (high-density housing). Natural shores was transformed into beaches, and fishing was developed [MICHALCZYK, WILGAT 1998].

The construction of Wieprz-Krzna drainage system caused an increase in the length of watercourses and ditches almost triply in this area. This is also confirmed by very large changes in the hydrographic network in the catchment area of Uściwierskie lakes. The size of water reservoirs has also slightly changed [GRZYWNA, NIEŚCIORUK 2016]. Some of them have completely changed the shape of the shoreline. The consequence was the reduction in water surface of lakes.

Generally lakes in Poland show the tendency to decrease both in area and number [CHOIŃSKI 2006]. Lake basin are subjected to constant evolution. Causes of changes are both natural and human activity. Among natural factors the most important role play: water level fluctuation, climate changes, depth of lake basin, hydrographic network etc. The most important anthropogenic factors are: hydrotechnical works, deforestration, agriculture [CHOIŃSKI et al. 2011; KANIECKI 1997].

The changes that occurred during the 78 years in the catchment area use were very clear. The largest changes related to urbanization, occurred in the catchment area of the lake Łukcze. Recreational buildings, mainly on the eastern shore of the lake, occupy $26 \%$ of the catchment area. In contrast, a positive phenomenon is the appearance of forest and grasslands in place of bushes. Urban pressure, only in the case of Lake Rogóźno is not noticeable. This is due to the fact, that the lake is still surrounded by woods and wetlands.

In catchments of most studied lakes increased the surface of buildings and forests. Similarly, increased 
the length of roads and watercourses. This was related to the settling of new areas and the construction of a network of drainage canals. Almost completely disappeared bushes and wastelands. Decreased the area of wetlands and arable lands. The observed changes in use are not indifferent to the lakes. A positive seems to increase wooded areas [SKONIECZEK et al. 2013]. While alarming, intensive development of infrastructure on the shores of lakes, affecting their degradation [KORNAŚ, GRZEŚKOWIAK 2011], as well as the disappearance of wetlands. The wetlands retreating was associated with a lowering of the water level, which resulted in mineralization of peat. This caused in an increase of lake trophy, overgrowing and degradation eventually [KORNIJÓw 1997; KRUK 2000]. Apart from the lake Rogóźno, which was mesotrophic, studied lakes were strongly eutrophic. While, at the end of $50 \mathrm{~s}$, most of them was in a group of low eutrophic lakes [WoJCIECHOWSKA, SOLIS 2009]. The studied lakes have fewer possibilities to self-cleaning because, in large part, they are shallow lakes.

We can counteract the negative effects of KWK drainage system of agricultural land by [PICHLA, JAKIMIUK 2014; WZMiUW 2008]:

- exclusion from this system some peat bogs and aquatic ecosystems,

- utilization of own water resources for intensive irrigation of peat bog ecosystems, especially in times of meteorological drought,

- water supplied from the Wieprz River for intensive irrigation the meliorated farmlands, in order to inhibit mineralization of organic soils and nitrogen and iron runoff from the surface zone to aquifers,

- restoring of degraded grasslands for production of energy crops in order to preserve the diversity of habitats.

\section{CONCLUSIONS}

1. The water surface in the lakes has decreased slightly (decrease the water table, the cover with rushes).

2. The water surface in the Krzczen reservoir increased threefold (construction of embankments around the reservoir, the water supply from KWK).

3. The length of watercourses in the study area increased (construction of drainage ditches).

4. In the catchment areas of studied lakes decreased surface area both wetlands and arable lands. While increased the area of forests and buildings.

\section{Acknowledgements}

The project Corine Land Cover 2012 in Poland was implemented by the Institute of Geodesy and Cartography and finance by the European Union. The results of the Project were obtained from the website of the Environmental Protection Inspectorate clc.gios.gov.pl. Maps changed by increasing the number and resolution of the layers.

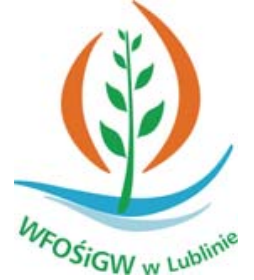

Dofinansowano ze środków Wojewódzkiego Funduszu Ochrony Środowiska

i Gospodarki Wodnej w Lublinie

Cofinanced by Voivodeship Fund

for Environmental Protection

and Water Management in Lublin

\section{REFERENCES}

ChMielewsKi T.J. (ed.) 2009. Ekologia krajobrazów hydrogenicznych Rezerwatu Biosfery Polesie Zachodnie [Ecology of hydrogenic landscapes of the "West Polesie" Biosphere Reserve]. Lublin. Wydaw. UP. ISBN 978-83-62860-10-4 pp. 344.

ChMielewski T.J., RaDWAN S. 1993. Zmiany stosunków ekologicznych w rejonie Poleskiego Parku Narodowego w ostatnich 75 latach. W: Ekosystemy wodne i torfowiskowe w obszarach chronionych [Changes in ecological relationships in the Polesie National Park area over the last 75 years. In: Aquatic and bog ecosystems in protected areas]. Eds S. Radwan, Z. Karbowski, M. Sołtys. Materiały konferencji „Funkcjonowanie ekosystemów wodnych i torfowiskowych w obszarach chronionych". Krasne, 28-29 July 1993. Lublin. TWWP, PPN p. 13-25.

ChorŃski A. 2006. Katalog jezior Polski [Catalogue of Polish lakes]. Poznań. Wydaw. Nauk. UAM. ISBN 83232-1732-7 pp. 600.

Choiński A., Ławniczak A., Ptak M., Sobkowiak L. 2011. Causes of lake area changes in Poland. Journal of Resources and Ecology. Vol. 2. No. 2 p. 175-180.

CZARNeCKa H. (ed.) 2005. Atlas podziału hydrograficznego Polski [Atlas of the hydrographic divisi on of Poland].Warszawa. PWN. ISBN 9788388897665 pp. 562.

GRZYwNA A., MAZUR A. 2014. Zmiany warunków wodnych w zlewni rzeki Tyśmienicy [The changes in water relations in the catchment basin of river Tysmienica]. Inżynieria Ekologiczna. Nr 38 p. 136-142.

GrZYwnA A., NiEŚCIORUK K. 2016. Changes of hydrographic network of Uściwierskie Lowering according to cartographic materials. Journal of Ecological Engineering. Vol. 17. Iss. 4 p. 148-153.

HARASIMIUK M., MichalCZYK Z., TURCZYŃSKi M. (ed.) 1998. Jeziora Łęczyńsko-Włodawskie. Monografia przyrodnicza [Lakes Łęczna and Włodawa. Natural monograph]. Lublin. Wydaw. UMCS. ISBN 8322712243 pp. 208.

KAJAK Z. 2001. Hydrobiologia - Limnologia. Ekosystemy wód śródlądowych [Hydrobiology - Limnology. Inland water ecosystems]. Warszawa. PWN. ISBN 8301125373 pp. 359.

KANIECKI A. 1997 Wpływ XIX-wiecznych melioracji na poziom wód. W: Wpływ antropopresji na jeziora [Influence of reclamation in the 19th century on changes in water level. In: Influence of anthropopression on lakes]. Ed. A. Choiński. Poznań-Bydgoszcz. Wydaw. Homini p. $67-72$.

KondRACKI J. 2002. Geografia fizyczna Polski [Polish physical geography]. Warszawa. PWN. ISBN 978-8301144-26-5 pp. 450.

KORNAŚ M., GRZEŚKOWIAK A. 2011. Wpływ użytkowania zlewni na kształtowanie jakości wody w zbiornikach wodnych zlewni rzeki Drawa [The impact of land use on water quality in water reservoirs of the Drawa River 
catchment]. Woda-Środowisko-Obszary Wiejskie. T. 11 Z. 1 (33) p. 125-137.

KORNIJÓw R. 1997. O zarastaniu jezior łęczyńsko-włodawskich $\mathrm{z}$ punktu widzenia ich funkcjonowania i ochrony [About overgrowing lakes Łęczna and Włodawa from of their functioning and protection]. Ekoinżynieria. Nr 4 p. 36-38.

Kowalik T., Kanownik W., Bogdal A., Policht-LataWIEC A. 2014. Wpływ zmian użytkowania zlewni wyżynnej na kształtowanie jakości wody powierzchniowej [Effect of change of small upland catchment use on surface water quality course]. Rocznik Ochrony Środowiska. T. 16. p. 223-238.

KRUK M. 2000. Biogeochemical functioning of hydrologically modified peatlands and its effect in eutrophication of freshwaters. Polish Journal of Ecology. Vol. 48. No. 2 p. $103-161$.

KRUKOWSKA R. 2007. Użytkowanie turystyczne jezior Pojezierza Łęczyńsko-Włodawskiego. W: Studia nad turystyką. [Land use of tourists lakes Łęczna and Włodawa Lakeland]. Eds W. Kurek, R. Faracik. Prace geograficzne i regionalne. Kraków. UJ p. 77-84.

MaŚlAnKo W., SENDER J. 2012. Stan ekologiczny jeziora Krasne w oparciu o wskaźniki makrofitowe oraz analiza struktury użytkowania jego zlewni na Pojezierzu Łęczyńsko-Włodawskim [Krasne Lake ecological state based on macrophytes indexes and analysis of land use in the catchment area]. Episteme. No. 14 p. 109-120.

MichalcZYK Z., Wilgat T. 1998. Stosunki wodne Lubelszczyzny [Water relations of the Lublin region]. Lublin. UMCS. ISBN 83-227-1148-4 pp. 167.

PICHLA A., JAKIMIUK S. 2014. Budowle wodne i melioracyjne Lubelszczyzny [Water and hydro-engineering structures in the Lublin region]. Infrastruktura i Ekologia Terenów Wiejskich. Z. 2. Nr 1 p. 173-193.
RADWAN S., KoRNIJÓw R. 1994. Hydrobiologiczna i hydrochemiczna charakterystyka wód powierzchniowych. W: Środowisko przyrodnicze w strefie oddziaływania Kanału Wieprz-Krzna [Hydrobiology and hydrochemical conditions water surface. In: Natural environment in the canal Wieprz-Krzna impact zone]. Lublin. AR, TWWP p. 47-58.

SKonieCzeK P., Koc J., Duda M. 2013. Wpływ zbiorników retencyjnych $\mathrm{w}$ ochronie jezior przed zanieczyszczeniami spływającymi z obszarów wiejskich [Effect of retention reservoirs in protecting lakes from runoff pollution in rural areas]. Proceedings of ECOpole. T. 7. $\mathrm{Nr} 1$ p. $247-252$.

Smoroń S., Kowalczyk A., Kostuch M. 2009. Użytkowanie gruntów zlewni rzeki Szreniawa w kontekście ochrony gleby i wody w latach 1995-2005 [Land use in the Szreniawa catchment area in the context of soil and water protection in the years 1965-2005]. WodaŚrodowisko-Obszary Wiejskie. T. 9. Z. 3 (27) p. 167177.

Solis M. 2012. Wpływ Kanału Wieprz-Krzna na właściwości fizyczno-chemiczne i biologiczne wód w wybranych zbiornikach retencyjnych [Impact of Wieprz-Krzna canal on physical-chemical and biological characteristics in selected storage reservoirs]. Inżynieria Ekologiczna. Nr 29 p. 182-191.

Wilgat T. 1954. Jeziora Łęczyńsko-Włodawskie [Lakes Łęczna-Włodawa]. Annales UMCS. Sect. B. $\mathrm{Nr} 8$ p. 37-122.

WoJCIECHOWSKA W., SOLIS M. 2009. Glony pro- i eukariotyczne jezior Pojezierza Łęczyńsko-Włodawskiego [Pro and eukaryotic alga lakes Łęczna-Włodawa Lakeland]. Lublin. Wydaw. KUL. ISBN 978-83-7363-906-5 pp. 86.

WZMiUW 2008. Program ochrony przed suszą [Drought protection program]. Lublin. pp. 308.

\section{Antoni GRZYWNA, Joanna SENDER}

\section{Zmiany użytkowania terenu w zlewniach jezior położonych w górnym biegu rzeki Tyśmienicy}

\section{STRESZCZENIE}

Na podstawie map topograficznych w skali 1: 50000 z 1936 i 2014 roku zaprezentowano zmiany w zagospodarowaniu terenu w zlewniach jezior. Do badań wybrano trzy naturalne jeziora (Rogóźno, Krasne, Łukcze) i jedno jezioro przekształcone w zbiornik retencyjny (Krzczeń). Do analiz wykorzystano program ArcGIS. W krajobrazie Pojezierza Łęczyńsko-Włodawskiego do końca XIX wieku dominowały mokradła i zakrzaczenia. Pierwszym rodzajem presji był rozwój rolnictwa. Kolejnym rodzajem presji krajobrazowej był rozwój rekreacji. W zlewniach badanych jezior zwiększyła się powierzchnia zabudowań i lasów. Zwiększyła się także długość dróg i cieków. Niemal całkowicie zanikły zakrzaczenia i nieużytki. Zmniejszyła się także powierzchnia mokradeł i gruntów ornych. Prawdopodobną przyczyną było obniżenie się lustra wody, a co za tym idzie - zarastanie użytkowanych ekstensywnie łąk i terenów podmokłych.

Słowa kluczowe: mapa topograficzna, rzeka Tyśmienica, użytkowanie terenu, zlewnia jeziora 